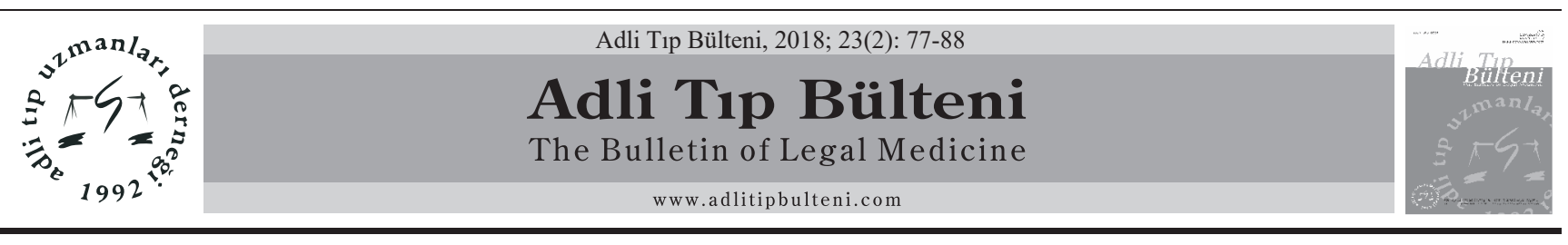

\title{
Meslekte Kazanma Gücü Kaybı Oranları ile Takdir Oranlarının Değerlendirilmesi: Muğla Sıtkı Koçman Üniversitesi Tıp Fakültesi Adli Tıp Anabilim Dalı Olguları
}

\author{
Permanent Disability Rating Determination and Clinical Regulation: Evaluation \\ of Cases of Muğla Sitkı Koçman University, Medical Faculty, Forensic Medicine \\ Department
}

\author{
Mehmet Resul Kadı ${ }^{1}$, Gülsüm Kadı ${ }^{2}$ Yasemin Balcı ${ }^{2}$, Ümit Ünüvar Göçeoğglu \\ ${ }^{1}$ Muğla Sttkı Koçman Üniversitesi Ĕ̆itim ve Araştırma Hastanesi Fiziksel Tip ve Rehabilitasyon Bölümü, Muğla \\ ${ }^{2}$ Muğla Sitkı Koçman Üniversitesi Tıp Fakültesi Adli Tıp Anabilim Dalı, Muğla
}

\section{Özet}

Amaç: Muğla Sıtkı Koçman Üniversitesi Tıp Fakültesi Adli Tıp Anabilim Dalına; meslekte kazanma gücü kayıp oranı tespiti amacıyla başvuran olguların kalıcı iş göremezlik oranları ve takdir oranlarının değerlendirmesi ile; hangi arızalara takdir uygulandığı ve takdir oranlarının neler olduğu ortaya konmuş, uygulama içinde ilgili Yönetmeliğin kısıtlılıkları tespit edilmeye çalışılmış ve öneriler geliştirmek amaçlanmıştır.

Gereç ve Yöntem: Haziran 2015-Aralık 2016 tarihleri arasında trafik kazası sonrası kalıcı sakatlık iddiası ile meslekte kazanma gücü kayıp oranı tespiti için başvuran 259 olgunun raporları geriye dönük değerlendirildi. Raporlarda kayıtlı, yaş, cinsiyet, kaza ile rapor düzenleme arasında geçen süre, arızaların dağılımı, iyileşme süreleri, hangi arızalar için takdir uygulandığı ve takdir oranları irdelendi. Veri analizinde, yüzde, oran, ortalama değerlerinin verildiği tanımlayıcı istatistikler kullanıldı.

Bulgular: Çalı̧̧ma Gücü ve Meslekte Kazanma Gücü Kayıp Oranı Tespit İşlemleri Yönetmeliğine göre meslekte kazanma gücünden kayıp oranı raporu düzenlenen 259 olgunun 182'si (\%70.3) erkek, 77'si (\%29.7) kadındı. En fazla olgu (\%45.2) 20-39 yaş grubundaydı. Kaza tarihi ve son muayene tarihi arasında geçen süre 1-111 ay arasında değişiyordu. Toplamda 73 olgudaki arızalara (\%23.1) takdir uygulanmıştı. Takdir uygulanan olguların arızaları ve takdir gerekçeleri ayrıntılı olarak tartışıldı ve ilgili Yönetmeliğin kısıtlılıkları ortaya konmaya çalışıldı.

Sonuç: İlgili Yönetmelikte farklı klinik durumları gözetecek şekilde oranlar belirlenmemiş olmasının bir kısıtllilık olduğu, bu konuda uygulama birliğine, güncel tedavi yaklaşımları düşünülerek arıza ağırlık cetvelinin yenilenmesine ve adli tıp ve branş hekimlerinin birlikte yürüteceği çok kapsamlı bir çalışmaya ihtiyaç olduğu kanısindayız.

Anahtar Kelimeler: Adli Tıp; Maluliyet; Meslekte Kazanma Gücü Kaybı; Takdir Oranları; Trafik Kazası.

Sorumlu Yazar: Dr. Gülsüm Kadı

Muğla Sıtkı Koçman Üniversitesi Tip Fakültesi Adli Tip Anabilim Dalı, Muğla

E-mail: gulsumkadi@gmail.com

Geliş: 08.01.2018Ｄüzeltme: 31.01.2018 Kabul: 02.02.2018

\begin{abstract}
Objective: Evaluation of the permanent disability rates and clinical regulation rates of the cases of Muğla Sttkı Koçman University, Medical Faculty, Forensic Medicine Department. Which disabilities are appraised and the rate of appreciation are revealed. The aim is to determine the limitations of the relevant Regulation in the application and to develop suggestions.
\end{abstract}

Materials and Methods: Between June 2015-December 2016, the reports of 259 patients who applied for disability rate determination by claiming permanent disability after a traffic accident were retrospectively evaluated. Age, gender, time between accident and medical report, disability distribution, recovery periods, which disability appraisal was applied and the discretion rates were examined. In the data analysis, descriptive statistics were used in which percentage, ratio, mean values were given. A total of 73 disabled cases $(23.1 \%)$ were assessed with discretion. The disability and appraisal levels of appraisal cases are discussed in detail and the limitations of the relevant regulation were tried to be revealed.

Results: 182 (70.3\%) males and 77 (29.7\%) females out of 259 cases who reported loss of strength in the profession according to Regulation of Permanent Disabilities. Most of the cases (45.2\%) were in the 20-39-age group. The time between the accident date and the last inspection date ranged from 1 to 111 months.

Discussion: It is a limitation of the relevant Regulation that rates are not determined according to different clinical situations. We think it is necessary to revise the permanent disability rating scale by taking into consideration the current treatment approaches and a comprehensive study to be carried out together with forensic medicine and other specialists in this regard.

Keywords: Forensic Medicine; Permanent Disability; Regulation of Permanent Disabilities; Disability Appraisal; Traffic Accident.

\section{Giriş}

Bir travma sonucu oluşan ve insan vücudunun bütünlüğünü farklı ağırlık derecelerinde bozan yaralanmaların ya da çalıştıkları meslekle ilgili ortam koşullarından ve bu ortamlarda kullanılan ajanlara bağlı olarak vücut organ ve dokularında meydana gelen arızaların, tüm tedavilerden sonra tamamen iyileşemeyip sekel hâlinde devam 
etmesi durumuna maluliyet ve vücut bütünlüğündeki eksiklik oranına da maluliyet derecesi denmektedir $(1,2)$. "Maluliyet derecesi", aynı zamanda "meslekte kazanma gücünden kayıp", "sürekli/kalıcı iş göremezlik" ya da "sakatlık" oranı olarak da ifade edilmektedir.

Meslekte kazanma gücü kayıp oranı "bazı parametreler temel alınarak hazırlanmış cetvellerden yararlanmak suretiyle tüm vücudun meslekte kazanma gücünden kayıp oranının saptanması" olarak tanımlanmaktadır (1). Maluliyet geçici, kalıcı, kısmi ya da tam olabilir. Bir ya da birden fazla hastalık/patoloji nedeniyle uzun süreli geçici ya da kalıcı olarak çalışma ve sosyal yaşamı devam ettirememe durumu kısmi ya da kalıcı maluliyet olarak tanımlanır. Kişinin vücut bütünlüğündeki eksiklik oranı maluliyet derecesi olarak ifade edilir; maluliyet sürekli bir iş göremezlik durumudur (3). Birçok ülkenin rehber ve yönetmenliklerinde bu oranlar hafif- orta- ağır derecede maluliyet ya da bakıma muhtaçlık şeklinde kategorize edilir (4).

Trafik kazaları nedeniyle yaralanan kişiler geçici ya da sürekli iş göremez kalabilmektedir. Sağlık sorunları, ekonomik ve sosyal boyutu ile trafik kazaları ülkemizde ve dünyada giderek artmaktadır. Dünyada yılda yaklaşık 15 milyon kişinin trafik kazalarında yaralandığ 1 , yaklaşık 1 milyon insanın da öldüğü bildirilmektedir (5). Türkiye İstatistik Kurumu (TUİK) 2015 y1lı verilerine göre, ülkemizde 1 milyon 313 binin üzerinde trafik kazası meydana geldiği, 183 binin üzerinde ise ölümlü yaralanmalı trafik kazası olduğu, 2016 yılında meydana gelen 185 binden fazla ölümlü yaralanmalı trafik kazası sonucunda; 7 bin 300 kişi öldüğü, 303 bin 812 kişinin yaralandığı bildirilmiştir $(6,7)$.

Kişilerin kaza sonrası uğradıkları zarar nedeniyle talep edebilecekleri maddi tazminat oranlarının belirlenebilmesi için, kişilerin meslekte kazanma gücünden kayıp oranları ya da sürekli iş göremezlik oranlarının tespit edilmesi gerekmektedir.

Türkiye'de trafik kazaları sonrası meydana gelen sekellerin oranlarının tespiti için 'travmaya özgü' bir cetvel bulunmamaktadır. Yargitay ve Sigorta Tahkim Kurulu maluliyet oranının tespiti açısından; 31.05.2006 tarih ve 5510 sayılı 'Sosyal Sigortalar ve Genel Sağlık Sigortası Kanununa dayanılarak hazırlanan ve 11.10.2008 tarih ve 27021 sayılı Resmî gazetede yayınlanan 'Çalışma Gücü ve Meslekte Kazanma Gücü Kayıp Oranı Tespit İşlemleri Yönetmeliği’nin (8) esas alınması ve buna göre rapor düzenlenmesini istemektedir $(9,10)$.

Bununla birlikte 14.05.2015 tarihli ve 29355 say1l Resmi Gazetede yayımlanan Karayolları Motorlu Araçlar Zorunlu Mali Sorumluluk Sigortası Genel Şartları ve 26.04.2016 tarih ve 29695 say1lı Resmi Gazetede yayım- lanarak yürürlüğe giren 6704 sayılı kanun ile 2918 sayılı Karayolları Trafik Kanununun 90. maddesinde yapılan değişiklikle; 'sürekli sakatlık tazminatına ilişkin sakatlık oranının belirlenmesinde, 30.03.2013 tarih ve 28603 sayılı Resmi Gazetede Özürlülük Ölçütü, Sınıflandırılması ve Özürlülere Verilecek Sağlık Kurulu Raporları Hakkında Yönetmelik (11) doğrultusunda hazırlanacak sağlık kurulu raporu dikkate alınmaktadır' şeklinde ifadeye yer verilmiştir $(4,12)$.

Ülkemizde kullanılan her iki cetvel de 'travmaya' özgü düzenlenmemiştir. Çalışma Gücü ve Meslekte Kazanma Gücü Kayıp Oranı Tespit İşlemleri Yönetmeliği, çalışan insanların, mesleğini yapabilmelerini göz önüne alarak düzenlenirken, Özürlülük Ölçütü, Sınıflandırılmas1 ve Özürlülere Verilecek Sağlık Kurulu Raporları Hakkında Yönetmelik ise kişilerin pek çok özlük hakları ile ilişkili (özürlü kontenjanından yaralanma, asker malullüğü, bakım, korunma ve rehabilitasyon gereksinimleri, sosyal destek ve yardım hizmetlerinin yürütülmesi, vergi indiriminden yaralanma gibi) özürlülüklerinin belirlenmesi için düzenlenmiştir. İki cetvel de travmatik durumların kişilerde bırakmış olduğu sekellere özgü değildir. Bununla birlikte halen bu iki cetvelden yararlanılarak bir oran verilmektedir.

Günümüzde hasar-danışmanlık şirketlerinin artması ve insanların hak arama konusunda bilinçlenmesi nedeniyle, kaza ve yaralanma durumlarında kalıcı iş göremezlik oranı, geçici iş göremezlik süresi, sürekli bakıma muhtaçlık, tedavi giderleri konusunda rapor talepleri de artmaktadır. Trafik kazası geçiren ve bu kaza sonucu yaralanan kişiler; bu yaralanmadan dolayı kalan sekellerinden dolayı tazminat talep edebilmektedir. Yargitay; maluliyetiş göremezlik- oranları için, Adli Tıp Kurumu ya da Üniversite Hastanelerinin Adli Tıp Anabilim Dallarınca ilgili Yönetmelik (Çalışma Gücü ve Meslekte Kazanma Gücü Kayıp Oranı Tespit İşlemleri Yönetmeliği) esas alınarak rapor düzenlenmesi gerektiğini hüküm altına almıştır (Yargitay 17. Hukuk Dairesi, 2015 tarih-2013/18924 Esas, 2014/18243 Esas, 2016/11897 Karar no).

Anabilim Dalımızda 2015 yılından bu yana ilgili kararlar doğrultusunda trafik kazaları sonrası meydana gelen sakatlıklarda meslekte kazanma gücü kaybı oranları için hasta kabul ederek rapor düzenlHemeye başlamıştır.

$\mathrm{Bu}$ hastaların değerlendirmesinde öncelikle; kaza ile sekel oluşturan yaralanma arasında nedensellik olmas1, yaralanma sonunda oluşan sekel kalıcı/sürekli olması, dolayısıyla maluliyetin kalıcı nitelik kazanması için iyileşme sürecinin tamamlanmış olması gerekmektedir. Maluliyet derecesinin hesaplanmasında kullanılan cetvellerin de hesabı yapacak olan hekimler tarafindan iyi biliniyor olması önemlidir. Yönetmelik ekinde yer alan 
arıza ağırlık listeleri, her kişide oluşabilecek farklı klinik durumlara göre karşılaşılan sekel ve kısıtll1ıkları tam olarak karşılamadığından, rapor düzenleyen uzmanlar tarafından bazı arızaların ağırlığı takdiren belirlenmekte ve aynı düzeydeki sekelin oranı rapor alınan yere göre farkl1lık arz edebilmektedir $(1,4,13)$.

$\mathrm{Bu}$ çalışmada, Anabilim Dalımızda düzenlenen meslekte kazanma gücü kayıp oranı tespiti raporlarına konu olan olguların demografik verileri yanı sıra, Yönetmelik ekindeki arıza listelerinde bildirilen kısıtlılıkların oranları ile kişilerin klinik durumlarına göre takdir uygulanan olguların verileri değerlendirilmiştir. Hangi arızalara takdir uygulandığı ve takdir oranlarının neler olduğu vurgulanarak, uygulama içinde ilgili Yönetmelik ekindeki cetvellerin kısıtlllıkları tespit edilmeye çalışılmış ve öneriler geliştirmek amaçlanmıştır.

\section{Gereç ve Yöntem}

Muğla Sıtkı Koçman Üniversitesi Tıp Fakültesi Adli Tip Anabilim Dalına Haziran 2015-Aralık 2016 tarihleri arasında yaklaşık 1.5 yıllık süreçte trafik kazası sonrası kalıcı sakatlık iddiası ile maluliyet oranının tespiti için başvuran olgular çalışmaya dahil edildi. Sekeli ile başvuruya konu kazası arasında nedenselliği olan 259 olgunun, meslekte kazanma gücü kayıp oranlarının tespit edildiği raporlar geriye dönük değerlendirildi. Raporlarda kayıtl1, yaş, cinsiyet, kaza ile rapor düzenleme arasında geçen süre, arızaların dağılımı, iyileşme süreleri, hangi arızalar için takdir uygulandığı ve takdir oranları irdelendi, literatür eşliğinde tartışıldı. İstatistiki veriler SPSS 22 programı kullanılarak çalışıldı, tablo ve grafikler program aracılığı ile yapıldı. Olguların yaşları; 0-19, 20-39, 40-59, 60 yaş ve üstü şeklinde gruplandırıldı. Veri analizinde, yüzde, oran, ortalama değerlerinin verildiği tanımlayıcı istatistikler kullanıldı. Çalışmanın etik kurul izni Muğla Sıtkı Koçman Üniversitesi’nden alınmıştır.

\section{Bulgular}

Maluliyet raporu düzenlenen 259 olgunun 182'si (\%70.3) erkek, 77'si (\%29.7) kadındı. İş göremezlik oran1 tespiti için gelen olguların en küçüğünün 8 , en büyü-

Tablo 1. Olguların yaş gruplarına göre dağılımı.

\begin{tabular}{|l|l|l|}
\hline Yaş grubu & N & $\%$ \\
\hline $0-19$ & 32 & 12,3 \\
\hline $20-39$ & 117 & 45,2 \\
\hline $40-59$ & 81 & 31,3 \\
\hline 60 ve üstü & 29 & 11,2 \\
\hline Toplam & 259 & 100 \\
\hline
\end{tabular}

günün 82 yaşında olduğu görüldü. Olguların 15 'i (\%5.8) 18 yaşından küçüktü. Tablo 1'de olguların yaş gruplarına göre dağılımı verilmiștir.

Olguların 35'i (\% 13.5) Hukuk Mahkemelerinden gönderilmiști, 224'ü (\%86.5) özel bașvuru ile kabul edilmiști.

Engelli kontenjanından Spor Bilimleri Fakültesine kayıt yaptırmak için başvuran 5 olgu bulunmaktaydı. Diğer olguların hepsi bir trafik kazası sonrası yaralanma nedeniyle başvurmuştu.

Kaza nedeni ile meslekte kazanma gücü kayıp oranı belirlenen olgularda $(\mathrm{n}=254)$, kaza tarihi ve son muayene tarihi arasında geçen sürenin dağılımına bakıldığında; en erken 1 ay, en geç 111 ay olduğu görüldü. Raporu yazılan olguların kazadan sonra geçen süreye göre dağılımı Tablo 2'de gösterilmiştir.

Toplam 21 olguya kaza sonrası ilk altı ay içinde, 57 olguya kaza sonrası 7-12 aylık süre içinde meslekte kazanma gücü kaybı oranı için rapor düzenlenmişti. Geri kalan 181 olgunun başvuru süresinin 12 ayın üzerinde olduğu görüldü. Tablo 3, kazadan sonraki ilk 6 ay içinde raporu düzenlenen olguların arızalarının dağılımını vermektedir. Bu olguların üçünde maluliyete esas alınan 2 arıza mevcut olup, bunların ikisinde Balthazar formülü uygulanmış, 1'inde arızalar aynı temel nedene bağlı olduğundan Balthazar formülü uygulanmamıştır. Dolayısıyla tabloda toplam olgu sayısı 24 olarak görülmektedir.

57 olguda kazadan sonraki 6-12 aylık süre içinde meslekte kazanma gücü kaybı oranı tespiti raporu düzenlendiği görüldü. $\mathrm{Bu}$ olguların 36'sında maluliyete esas alınan tek bir arıza, 16 olguda 2 arıza ve 5 olguda 3 farklı arıza mevcuttu. Birden fazla arızası olan olguların 19'unda Balthazar formülü uygulanmış, 2'sinde arızalar aynı temel nedene bağlı olduğundan Balthazar formülü uygulanmamıştı. Kazadan sonraki 6-12 ay içinde raporu düzenlenen olguların arızalarına göre dağılımı Tablo 4'de gösterilmiştir.

Tablo 2. Kaza tarihi ile meslekte kazanma gücü kayıp oranının belirlendiği son muayene tarihi arasında geçen sürelerin dağılımı.

\begin{tabular}{|l|l|l|}
\hline Geçen süre (ay) & N & $\%$ \\
\hline $0-6$ & 21 & 8,3 \\
\hline $7-12$ & 57 & 22,4 \\
\hline $13-18$ & 75 & 29,5 \\
\hline $19-24$ & 39 & 15,4 \\
\hline $25-30$ & 18 & 7,1 \\
\hline $31-36$ & 14 & 5,5 \\
\hline 37 ve üstü & 30 & 11,8 \\
\hline Toplam & 254 & 100 \\
\hline
\end{tabular}


Tablo 3. Kazadan sonraki ilk 6 ay içinde rapor düzenlenen olguların arızalarının dağılımı.

\begin{tabular}{|l|l|l|}
\hline Arıza & $\mathrm{n}$ & $\%$ \\
\hline Splenektomi & 16 & 66,7 \\
\hline Tam görme kaybı & 2 & 8,3 \\
\hline Vertebra kompresyon kırığı & 2 & 8,3 \\
\hline Vertebra posterior eleman kırığ1 & 2 & 8,3 \\
\hline Humerus kırığı & 1 & 4,2 \\
\hline Tibia kıı̆ı̆ı & 1 & 4,2 \\
\hline Toplam & 24 & 100 \\
\hline & &
\end{tabular}

Tablo 4. Kazadan sonraki 6-12 ay içinde raporu düzenlenen olgulardaki arızaların dağılımı.

\begin{tabular}{|c|c|c|}
\hline Arıza & $\mathrm{n}$ & $\%$ \\
\hline Tibia-fibula kırı̆̆g & 16 & 20,5 \\
\hline Femur kırı̆ğ & 11 & 14,1 \\
\hline Vertebra posterior eleman kırığ1 & 10 & 12,9 \\
\hline Humerus ve/veya radius kırığ & 6 & 7,7 \\
\hline Vertebra kompresyon kırığı & 5 & 6,4 \\
\hline Sinir hasarları & 5 & 6,4 \\
\hline Amputasyonlar & 3 & 3,8 \\
\hline Tam görme kayb1 & 1 & 1,3 \\
\hline Aşil tendon yırtı̆̆ 1 & 1 & 1,3 \\
\hline Alt ekstremitede çoklu kırıklar & 2 & 2,3 \\
\hline Pelvis kırı̆̆ı ve/veya kalça protezi & 4 & 5,1 \\
\hline Hemiparezi & 2 & 2,3 \\
\hline Olecranon kırı̆̆ 1 & 1 & 1,3 \\
\hline Patella kırı̆̆ 1 & 3 & 3,8 \\
\hline Akciğer kontüzyonu & 1 & 1,3 \\
\hline Klavikula ve/veya skapula kırığı & 2 & 2,3 \\
\hline Genişs skarlar & 2 & 2,3 \\
\hline Talus kırı ̆̆ı & 1 & 1,3 \\
\hline El bilek ve/veya parmak kırığı & 2 & 2,3 \\
\hline Organik akıl hastalığ & 1 & 1,3 \\
\hline Toplam & 78 & 100 \\
\hline
\end{tabular}

Maluliyet raporu düzenlenen 259 olgunun 196'sında temel olarak bir arıza olduğu, 63'ünde ise birden fazla arıza olduğu tespit edilmişti; bunların 50'sinde 2 arıza, 9 olguda 3 arıza, 3 olguda 4 arıza ve bir olguda 5 farklı ar1za olduğu görüldü. Birden fazla arızası olan 63 olgunun 53'üne Balthazar formülü uygulanmış, 10 olguda oluşan sekeller aynı temel nedene bağlı olduğundan Balthazar formülü uygulanmamışt1.
Tablo 5. Olguların iyileşme sürelerinin dağılımı.

\begin{tabular}{|l|c|}
\hline İyileşme süresi & $\mathrm{n}$ \\
\hline 30 gün ve altı ( $\leq 1$ ay) & 5 \\
\hline 45 gün (1.5 ay) & 4 \\
\hline 60 gün (2 ay) & 114 \\
\hline 90 gün (3 ay) & 19 \\
\hline 120 gün (4 ay) & 4 \\
\hline 150 gün (5 ay) & 46 \\
\hline 180 gün (6 ay) & 1 \\
\hline 210 gün (7 ay) & 1 \\
\hline 240 gün (8 ay) & 9 \\
\hline 270 gün (9 ay) & 4 \\
\hline 300 gün (10 ay) & 1 \\
\hline 330 gün (11 ay) & 7 \\
\hline 360 gün (12 ay) & 5 \\
\hline 365 gün (1 y1l) & 249 \\
\hline Toplam & \\
\hline
\end{tabular}

Geçici iş göremezlik süresinin -iyileşme süresi- 249 olgu için verildiği görüldü. En kısa iyileşme süresi 20 gün, en uzun iyileşme süresi 365 gün olarak belirlenmişti. Olguların iyileşme sürelerinin dağılımı Tablo 5'de gösterilmiştir.

Engelli kontenjanından Spor Bilimleri Fakültesine kayıt yaptırmak için başvuran 5 olgu dışında, bir trafik kazası sonrasında meslekte kazanma gücü kaybı oranı belirlenen 254 olgunun 222 'sinin (\% 87.4) ameliyat olduğu tespit edildi. Ameliyat olan 222 olgunun 11 'inde kişilerin olay nedeniyle $3 \mathrm{kez}$ ve daha fazla ameliyat olmak zorunda kaldıkları görüldü. Ameliyat olan 222 olgunun 18'inde kırık/kırıkların kaynamaması ya da enfeksiyon gelişimi gibi komplikasyonlar bildirilmişti.

Çalışma Gücü ve Meslekte Kazanma Gücü Kayıp Oranı Tespit İşlemleri Yönetmeliği’nin eklerinde belirtilen arıza listelerinden; Liste 2 (Göz Arızaları), Liste 6 (Göğüs Hastalıkları), Liste 9 (El Parmakları Arızaları) ve Liste 11 (Karın Hastalıkları Arızaları)' de yer alan arızalar için herhangi bir takdir oranı uygulanmamıştı. Takdir uygulanan olguların; listesi ve aldığı tanılar, Arıza sıra no, Arıza ağırlık oranı ve kullanılan 'takdir' oranlarının dağılımı Tablo 6, 7 ve 8'de gösterilmiştir. Olgular birden fazla arıza içermektedir, tablolarda her bir arıza tek tek verilmiştir. 
Tablo 6. Olguların 1., 2., 4., 6., 7. Arıza Listelerine göre tanıları, arıza ağırlık ölçüsü ve takdir oranlarının dağılımı.

\begin{tabular}{|c|c|c|c|c|c|}
\hline Ariza & $\mathbf{n}$ & Arıza Sira No & \begin{tabular}{|c|}
$\begin{array}{c}\text { D Cetveline göre } \\
\text { oran }\end{array}$ \\
\end{tabular} & $\begin{array}{c}\text { Takdir ile } \\
\text { verilen oran }\end{array}$ & $\begin{array}{l}\text { Takdir } \\
\text { Oranı }\end{array}$ \\
\hline \multicolumn{6}{|c|}{ Liste 1. Baş Arızaları (n:13) } \\
\hline Anksiyete & 2 & $16(n: 2)$ & $49(n: 2)$ & $\begin{array}{l}25(\mathrm{n}: 1) \\
10(\mathrm{n}: 1)\end{array}$ & $\begin{array}{l}1 / 2 \\
1 / 5\end{array}$ \\
\hline Depresyon & 2 & $16(\mathrm{n}: 2)$ & 49 (n:2) & $\begin{array}{c}5(\mathrm{n}: 1) \\
16(\mathrm{n}: 1)\end{array}$ & $\begin{array}{c}1 / 10 \\
1 / 3 \\
\end{array}$ \\
\hline Polinöropati & 1 & $14(\mathrm{n}: 1)$ & $49(\mathrm{n}: 1)$ & & \\
\hline Spastik paraparezi & 1 & $6(\mathrm{n}: 1)$ & $35(\mathrm{n}: 1)$ & & \\
\hline Kraniektomi & 1 & $1(\mathrm{n}: 1)$ & $34(\mathrm{n}: 1)$ & & \\
\hline Hemiparezi & 2 & $6(\mathrm{n}: 2)$ & $\begin{array}{l}39(\mathrm{n}: 1) \\
65(\mathrm{n}: 1)\end{array}$ & & \\
\hline Hemipleji & 1 & $6(\mathrm{n}: 1)$ & $62(\mathrm{n}: 1)$ & & \\
\hline Kontüzyocerebri & 2 & $12(\mathrm{n}: 2)$ & $\begin{array}{c}49(\mathrm{n}: 1) \\
100(\mathrm{n}: 1)\end{array}$ & & \\
\hline Organik akıl hastalığ1 & 1 & $12(\mathrm{n}: 1)$ & $49(\mathrm{n}: 1)$ & & \\
\hline \multicolumn{6}{|c|}{ Liste 2. Göz Arızaları (n:3) } \\
\hline Körlük & 3 & $\begin{array}{c}1(\mathrm{n}: 2) \\
11(\mathrm{n}: 1)\end{array}$ & $39(\mathrm{n}: 3)$ & - & \\
\hline \multicolumn{6}{|c|}{ Liste 4. Yüz Arızaları (n:2) } \\
\hline Anosmi & 1 & $6(n: 1)$ & $14(\mathrm{n}: 1)$ & - & \\
\hline Malokluzyon ve yüz kemiklerinde kırık & 1 & $1(\mathrm{n}: 1)$ & $45(\mathrm{n}: 1)$ & $15(\mathrm{n}: 1)$ & $1 / 3$ \\
\hline \multicolumn{6}{|c|}{ Liste 6. Göğüs Arızaları (n:4) } \\
\hline Kot kırı̆g1 & 2 & $1(n: 2)$ & $10(\mathrm{n}: 2)$ & - & \\
\hline Akciğer lobektomi & 1 & $1(\mathrm{n}: 1)$ & $10(\mathrm{n}: 1)$ & - & \\
\hline Akciğer kontüzyonu & 1 & $1(\mathrm{n}: 1)$ & $10(\mathrm{n}: 1)$ & & \\
\hline \multicolumn{6}{|c|}{ Liste 7. Omuz ve Kol Arızaları (n:43) } \\
\hline Ulna kırı̆̆1 & 2 & $12(\mathrm{n}: 2)$ & $11(\mathrm{n}: 2)$ & & \\
\hline Ulnar sinir hasarı & 2 & $19(\mathrm{n}: 2)$ & $51(\mathrm{n}: 2)$ & & \\
\hline Ön kol ampute & 1 & $7(n: 1)$ & $43(\mathrm{n}: 1)$ & & \\
\hline Skapula kırığ1 & 2 & $\begin{array}{l}2(\mathrm{n}: 1) \\
3(\mathrm{n}: 1)\end{array}$ & $\begin{array}{l}19(\mathrm{n}: 1) \\
34(\mathrm{n}: 1)\end{array}$ & $\begin{array}{c}5(\mathrm{n}: 1) \\
19(\mathrm{n}: 1)\end{array}$ & $\begin{array}{l}1 / 4 \\
1 / 2 \\
\end{array}$ \\
\hline Radius-ulna kırığı & 2 & $\begin{array}{c}2(\mathrm{n}: 1) \\
12(\mathrm{n}: 1)\end{array}$ & $16(\mathrm{n}: 2)$ & $\begin{array}{l}4(\mathrm{n}: 1) \\
9(\mathrm{n}: 1)\end{array}$ & $\begin{array}{l}1 / 4 \\
1 / 2 \\
\end{array}$ \\
\hline Radius ulna-patella kırığ1 & 1 & $12(\mathrm{n}: 1)$ & $17(\mathrm{n}: 1)$ & & \\
\hline Radial sinir hasarı & 3 & $19(\mathrm{n}: 3)$ & $51(\mathrm{n}: 3)$ & $\begin{array}{l}10(\mathrm{n}: 2) \\
34(\mathrm{n}: 1)\end{array}$ & $\begin{array}{l}1 / 10 \\
2 / 3 \\
\end{array}$ \\
\hline Olekranon kırığı & 2 & $\begin{array}{l}12(\mathrm{n}: 1) \\
14(\mathrm{n}: 1)\end{array}$ & $\begin{array}{l}14(\mathrm{n}: 1) \\
20(\mathrm{n}: 1)\end{array}$ & $10(\mathrm{n}: 1)$ & $1 / 2$ \\
\hline Radius kırığı & 2 & $\begin{array}{l}12(\mathrm{n}: 1) \\
15(\mathrm{n}: 1)\end{array}$ & $\begin{array}{l}11(\mathrm{n}: 1) \\
19(\mathrm{n}: 1)\end{array}$ & & \\
\hline Median ve ulnar sinir hasarı & 2 & $19(\mathrm{n}: 2)$ & $51(\mathrm{n}: 2)$ & $13(\mathrm{n}: 1)$ & $1 / 4$ \\
\hline Klavikula kırı̆g 1 & 1 & $1(\mathrm{n}: 1)$ & $3(\mathrm{n}: 1)$ & & \\
\hline Klavikula kırığı (kaynamayan) & 2 & $1(n: 2)$ & $3(\mathrm{n}: 2)$ & & \\
\hline Humerus $1 / 3$ ampute & 1 & $6(\mathrm{n}: 1)$ & $80(\mathrm{n}: 1)$ & & \\
\hline Humerus kırığ1 & 16 & $\begin{array}{c}2 \text { (n:3) } \\
3 \text { (n.8) } \\
12(\mathrm{n}: 2) \\
14(\mathrm{n} .2) \\
18(\mathrm{n}: 1)\end{array}$ & $\begin{array}{c}7 \text { (n:1) } \\
14(\mathrm{n}: 1) \\
19(\mathrm{n}: 10) \\
20(\mathrm{n}: 1) \\
34(\mathrm{n}: 3)\end{array}$ & $\begin{array}{c}6(\mathrm{n}: 1) \\
9(\mathrm{n}: 1) \\
10(\mathrm{n} .4) \\
13(\mathrm{n}: 3) \\
14(\mathrm{n}: 1)\end{array}$ & $\begin{array}{l}1 / 3 \\
1 / 2 \\
2 / 3\end{array}$ \\
\hline Humerus ve ulna kırığ1 & 1 & $3(\mathrm{n}: 1)$ & $19(\mathrm{n}: 1)$ & & \\
\hline Skapula ve klavikula kırığ1 & 1 & $3(\mathrm{n}: 1)$ & $19(\mathrm{n}: 1)$ & $6(\mathrm{n}: 1)$ & $1 / 3$ \\
\hline Omuz çıkı̆̆1 & 1 & $3(\mathrm{n}: 1)$ & $19(\mathrm{n}: 1)$ & $6(n: 1)$ & $1 / 3$ \\
\hline
\end{tabular}


Tablo 7. Olguların 8., 9., 10., 11. Arıza Listelerine göre tanıları, arıza ağırlık ölçüsü ve takdir oranlarının dağılımı.

\begin{tabular}{|c|c|c|c|c|c|}
\hline Ariza & n & Ariza Sira No & $\begin{array}{l}\text { D Cetveline göre } \\
\text { oran }\end{array}$ & $\begin{array}{l}\text { Takdir ile verilen } \\
\text { oran }\end{array}$ & $\begin{array}{l}\text { Takdir } \\
\text { Oranı }\end{array}$ \\
\hline \multicolumn{6}{|c|}{ Liste 8. El ve El Bileği Arızaları (n:16) } \\
\hline Radius kırığg & 9 & $2(n: 9)$ & $\begin{array}{l}16(\mathrm{n}: 8) \\
23(\mathrm{n}: 1)\end{array}$ & $\begin{array}{c}4(\mathrm{n}: 2) \\
5(\mathrm{n}: 4) \\
8(\mathrm{n}: 1) \\
11(\mathrm{n}: 2)\end{array}$ & $\begin{array}{l}1 / 4 \\
1 / 3 \\
1 / 2 \\
2 / 3 \\
\end{array}$ \\
\hline Ulna kırığ & 1 & $2(\mathrm{n}: 1)$ & $16(\mathrm{n}: 1)$ & $5(\mathrm{n}: 1)$ & $1 / 3$ \\
\hline Skafoid kırı ̆̆ 1 & 1 & $2(\mathrm{n}: 1)$ & $16(\mathrm{n}: 1)$ & $4(n: 1)$ & $1 / 4$ \\
\hline Skafoidpsöudoartrozu & 1 & $3(\mathrm{n}: 1)$ & $14(\mathrm{n}: 1)$ & & \\
\hline Radius-ulna kırığı & 2 & $2(\mathrm{n}: 2)$ & $16(\mathrm{n}: 2)$ & $4(\mathrm{n}: 1)$ & $1 / 4$ \\
\hline Radius kırık-ulna çıkı̆̆ı & 1 & $2(\mathrm{n}: 1)$ & $16(\mathrm{n}: 1)$ & $5(\mathrm{n}: 1)$ & $1 / 3$ \\
\hline Lunatum çıkığ1 & 1 & $2(\mathrm{n}: 1)$ & $13(\mathrm{n}: 1)$ & & \\
\hline \multicolumn{6}{|c|}{ Liste 9. El parmakları Arızaları (n:10), *dominant el farkı nedeniyle oran farkı olan olgular } \\
\hline 1. parmak DP* amputasyonu & 2 & $1(\mathrm{n}: 2)$ & $\begin{array}{l}22(\mathrm{n}: 1) \\
20(\mathrm{n}: 1)\end{array}$ & & \\
\hline $\begin{array}{l}\text { 2. parmak DP amputasyonu ve } 3 \text {. } \\
\text { parmak distal artrodezi }\end{array}$ & 1 & $10(\mathrm{n}: 1)$ & $7(\mathrm{n}: 1)$ & & \\
\hline $\begin{array}{l}\text { 5. parmak kırığı, } 5 \text { parmak PP* } \\
\text { kırığı }\end{array}$ & 2 & $5(n: 2)$ & $\begin{array}{l}5(\mathrm{n}: 1) \\
4(\mathrm{n}: 1)\end{array}$ & & \\
\hline 4.-5. parmak MKP* ankilozu & 1 & $15(\mathrm{n}: 1)$ & $13(\mathrm{n}: 1)$ & & \\
\hline Metakarp kırığı (4) & 4 & $\begin{array}{l}10(\mathrm{n}: 1) \\
12(\mathrm{n}: 1) \\
16(\mathrm{n}: 2)\end{array}$ & $\begin{array}{c}7(\mathrm{n}: 1) \\
9(\mathrm{n}: 1) \\
17(\mathrm{n}: 1) \\
29(\mathrm{n}: 1)\end{array}$ & & \\
\hline \multicolumn{6}{|c|}{ Liste 10. Omurga Arıaları (n:46) } \\
\hline $\begin{array}{l}1 \text { vertebra kompresyon kırığ } 1+1 \\
\text { vertebra kırığ } 1\end{array}$ & 1 & $1(\mathrm{n}: 1)$ & $31(\mathrm{n}: 1)$ & & \\
\hline $\begin{array}{l}1 \text { vertebra kompresyon kırığ } 1+ \\
\text { spondilolistezis }\end{array}$ & 3 & $\begin{array}{l}1(\mathrm{n}: 2) \\
2(\mathrm{n}: 1)\end{array}$ & $\begin{array}{l}10(\mathrm{n}: 1) \\
37(\mathrm{n}: 1)\end{array}$ & $11(\mathrm{n}: 1)$ & $1 / 3$ \\
\hline 1 vertebra kompresyon kırığ 1 & 12 & $1(12 \mathrm{olgu})$ & $\begin{array}{l}19(\mathrm{n}: 9) \\
26(\mathrm{n} 2) \\
35(\mathrm{n}: 1)\end{array}$ & $\begin{array}{l}14(\mathrm{n}: 2) \\
22(\mathrm{n}: 1)\end{array}$ & $\begin{array}{l}1 / 2 \\
1 / 3\end{array}$ \\
\hline 2 vertebra kompresyon kırığ 1 & 2 & $1(\mathrm{n}: 2)$ & $\begin{array}{l}19(\mathrm{n}: 1) \\
31(\mathrm{n}: 1)\end{array}$ & & \\
\hline 1 vertebra parçalı kırı̆ğ & 22 & $1(n: 22)$ & $\begin{array}{c}14(\mathrm{n}: 11) \\
19(\mathrm{n}: 9) \\
24(\mathrm{n}: 1) \\
26(\mathrm{n}: 1)\end{array}$ & $\begin{array}{l}14(\mathrm{n}: 1) \\
22(\mathrm{n}: 1)\end{array}$ & $\begin{array}{l}1 / 2 \\
2 / 3\end{array}$ \\
\hline 2 vertebra parçalı kırığ 1 & 4 & $1(n: 4)$ & $\begin{array}{l}14(\mathrm{n}: 2) \\
19(\mathrm{n}: 1) \\
24(\mathrm{n}: 1)\end{array}$ & & \\
\hline Skolyoz & 1 & $5(\mathrm{n}: 1)$ & $24(\mathrm{n}: 1)$ & & \\
\hline 1 vertebra posterior kırığ 1 & 1 & $1(\mathrm{n}: 1)$ & $14(\mathrm{n}: 1)$ & 7 (n:1) & $1 / 2$ \\
\hline \multicolumn{6}{|c|}{ Liste 11. Karın Hastalıkları ve Arızaları (n:24) } \\
\hline Splenektomi & 21 & $21(\mathrm{n}: 21)$ & $19(\mathrm{n}: 21)$ & & \\
\hline Kolesistektomi & 1 & $2(\mathrm{n}: 1)$ & $5(\mathrm{n}: 1)$ & & \\
\hline Nefrektomi & 1 & $4(\mathrm{n}: 1)$ & $29(\mathrm{n}: 1)$ & & \\
\hline Hemikolektomi & 1 & 2 (n:1) & $19(\mathrm{n}: 1)$ & & \\
\hline
\end{tabular}


Tablo 8. Olguların 12. ve 14. Arıza Listelerine göre tanıları, arıza ağırlık ölçüsü ve takdir oranlarının dağılımı.

\begin{tabular}{|c|c|c|c|c|c|}
\hline Ariza & n & Ariza Sira No & $\begin{array}{l}\text { D Cetveline } \\
\text { göre oran }\end{array}$ & $\begin{array}{c}\text { Takdir ile } \\
\text { verilen oran }\end{array}$ & $\begin{array}{l}\text { Takdir } \\
\text { Oranı }\end{array}$ \\
\hline \multicolumn{5}{|c|}{ Liste 12. Pelvis ve Alt Ekstremite Arızaları (n:156) } & \\
\hline Aşil tendon yırtığı & 1 & $28(\mathrm{n}: 1)$ & $14(\mathrm{n}: 1)$ & $9(\mathrm{n}: 1)$ & $2 / 3$ \\
\hline Ayak bileği ankilozu & 1 & $27(\mathrm{n}: 1)$ & $19(\mathrm{n}: 1)$ & & \\
\hline Ayak bileği dorsofleksiyon kısıtlılığı & 1 & $28(\mathrm{n}: 1)$ & $14(\mathrm{n}: 1)$ & & \\
\hline Ayak bileği planterfeksiyon $\% 50$ 'den az & 1 & $27(\mathrm{n}: 1)$ & $14(\mathrm{n}: 1)$ & & \\
\hline Ayak bileğinden amputasyon & 1 & $13(\mathrm{n}: 1)$ & $29(\mathrm{n}: 1)$ & & \\
\hline 3-5. Parmak ampütasyonu & 1 & $16(\mathrm{n}: 1)$ & $19(\mathrm{n}: 1)$ & & \\
\hline Diz içi bağ lezyonu & 1 & $23(\mathrm{n}: 1)$ & $24(\mathrm{n}: 1)$ & & \\
\hline Dizde fleksiyon kısıtlılığ 1 & 1 & $22(\mathrm{n}: 1)$ & $14(\mathrm{n}: 1)$ & & \\
\hline Bilateral kalça çıkığı & 1 & $34(\mathrm{n}: 1)$ & $24(\mathrm{n}: 1)$ & & \\
\hline Femurbaşı total protez & 1 & $11(\mathrm{n}: 1)$ & $44(\mathrm{n}: 1)$ & & \\
\hline Femur boyun kırığı parsiyelprotez & 2 & $11(\mathrm{n}: 2)$ & $34(\mathrm{n}: 2)$ & & \\
\hline Femur kırığ 1 & 36 & $\begin{array}{c}6(\mathrm{n}: 1) \\
10(\mathrm{n}: 1) \\
11(\mathrm{n}: 2) \\
20(\mathrm{n}: 2) \\
22(\mathrm{n}: 9) \\
32(\mathrm{n}: 9) \\
34(\mathrm{n}: 8) \\
35(\mathrm{n}: 4)\end{array}$ & $\begin{array}{c}3(\mathrm{n}: 2) \\
5(\mathrm{n}: 9) \\
7(\mathrm{n}: 5) \\
9(\mathrm{n}: 1) \\
14(\mathrm{n}: 7) \\
19(\mathrm{n}: 9) \\
25(\mathrm{n}: 1) \\
34(\mathrm{n}: 1) \\
44(\mathrm{n}: 1)\end{array}$ & $\begin{array}{c}6(\mathrm{n}: 7) \\
7(\mathrm{n}: 1) \\
9(\mathrm{n}: 2) \\
10(\mathrm{n}: 2) \\
19(\mathrm{n}: 1) \\
20(\mathrm{n}: 1)\end{array}$ & $\begin{array}{l}1 / 3 \\
1 / 2 \\
2 / 3\end{array}$ \\
\hline Femurkırığı psödoartroz & 2 & $10(\mathrm{n}: 2)$ & $44(\mathrm{n}: 2)$ & & \\
\hline Femur kırığı ve total kalça protezi & 3 & $11(\mathrm{n}: 3)$ & $\begin{array}{l}34(\mathrm{n}: 1) \\
44(\mathrm{n}: 2)\end{array}$ & & \\
\hline Femur + patellakırığg & 3 & $22(3 \mathrm{olgu})$ & $\begin{array}{l}14(\mathrm{n}: 1) \\
20(\mathrm{n}: 1) \\
29(\mathrm{n}: 1)\end{array}$ & & \\
\hline Fibulakırı ̆̆1 & 6 & $32(\mathrm{n}: 6)$ & $5(n: 6)$ & & \\
\hline Kalkaneuskırığı & 2 & $18(\mathrm{n}: 2)$ & $9(\mathrm{n}: 2)$ & & \\
\hline Menisküs ve bağ yırtığı & 1 & $22(\mathrm{n}: 1)$ & $24(\mathrm{n}: 1)$ & & \\
\hline Metatars eksikliği ve şekil bozukluğu & 1 & $19(\mathrm{n}: 1)$ & $14(\mathrm{n}: 1)$ & & \\
\hline Metatars+medialmalleolfraktürü & 1 & $28(\mathrm{n}: 1)$ & $14(\mathrm{n}: 1)$ & & \\
\hline Osteomyelit & 1 & $39(\mathrm{n}: 1)$ & $65(\mathrm{n}: 1)$ & & \\
\hline Patellakırığ 1 & 5 & $\begin{array}{l}22(\mathrm{n}: 4) \\
31(\mathrm{n}: 1)\end{array}$ & $\begin{array}{c}5(\mathrm{n}: 1) \\
14(\mathrm{n}: 2) \\
19(\mathrm{n}: 2)\end{array}$ & & \\
\hline Pelviskırığg & 11 & $\begin{array}{c}1(\mathrm{n}: 3) \\
2(\mathrm{n}: 1) \\
6(\mathrm{n}: 4) \\
7(\mathrm{n}: 1) \\
34(\mathrm{n}: 2)\end{array}$ & $\begin{array}{c}9(\mathrm{n}: 3) \\
19(\mathrm{n}: 2) \\
29(\mathrm{n}: 4) \\
34(\mathrm{n}: 1) \\
39(\mathrm{n}: 1)\end{array}$ & $\begin{array}{c}4(\mathrm{n}: 1) \\
6(\mathrm{n}: 1) \\
10(\mathrm{n}: 1) \\
19(\mathrm{n}: 1)\end{array}$ & $\begin{array}{l}1 / 2 \\
1 / 3\end{array}$ \\
\hline Bilateraltibia kırığ 1 & 1 & $32(\mathrm{n}: 1)$ & $\begin{array}{c}9(\mathrm{n}: 1) \\
19(\mathrm{n}: 1)\end{array}$ & & \\
\hline Diz altı ampütasyon & 1 & $12(\mathrm{n}: 1)$ & $49(\mathrm{n}: 1)$ & & \\
\hline
\end{tabular}




\begin{tabular}{|c|c|c|c|c|c|}
\hline Siyatik sinir hasarı & 3 & $\begin{array}{l}38(\mathrm{n}: 2) \\
45(\mathrm{n}: 1)\end{array}$ & $\begin{array}{l}4(\mathrm{n}: 1) \\
49(\mathrm{n}: 2) \\
\end{array}$ & & \\
\hline Sol patella ve sağ tibia kırı̆g & 1 & 22 & 19 & & \\
\hline Talus Kırı̆̆ 1 & 2 & $\begin{array}{l}28(\mathrm{n}: 1) \\
37(\mathrm{n}: 1)\end{array}$ & $\begin{array}{l}10(\mathrm{n}: 1) \\
19(\mathrm{n}: 1)\end{array}$ & & \\
\hline Tibia Kırı̆̆ 1 & 31 & $\begin{array}{l}22(\mathrm{n}: 13) \\
27(\mathrm{n}: 3) \\
28(\mathrm{n}: 3) \\
29(\mathrm{n}: 1) \\
32(\mathrm{n}: 9) \\
33(\mathrm{n}: 2)\end{array}$ & $\begin{array}{c}5(\mathrm{n}: 9) \\
11(\mathrm{n}: 3) \\
14(\mathrm{n}: 13) \\
19(\mathrm{n}: 5) \\
21(\mathrm{n}: 1)\end{array}$ & $\begin{array}{l}7(\mathrm{n}: 2) \\
9(\mathrm{n}: 1)\end{array}$ & $1 / 2$ \\
\hline Tibiakırığı, pnömosefali & 1 & $16(\mathrm{n}: 1)$ & 7 (n:1) & & \\
\hline Tibiakırığı+femurkırığı & 4 & $\begin{array}{l}22(\mathrm{n}: 3) \\
32(\mathrm{n}: 1)\end{array}$ & $\begin{array}{c}5(\mathrm{n}: 1) \\
14(\mathrm{n}: 2) \\
19(\mathrm{n}: 1) \\
\end{array}$ & & \\
\hline Femur + tibia + patella kırığı & 1 & $22(\mathrm{n}: 1)$ & $24(\mathrm{n}: 1)$ & & \\
\hline Tibiapsödoartrozu & 2 & $33(\mathrm{n}: 2)$ & $24(\mathrm{n}: 2)$ & & \\
\hline Tibia+fibula kırı̆ğ & 21 & $\begin{array}{l}22(n: 3) \\
27(n: 2) \\
28(n: 4) \\
32(n: 8) \\
33(n: 2) \\
37(n: 2)\end{array}$ & $\begin{array}{c}5(\mathrm{n}: 7) \\
6(\mathrm{n}: 1) \\
7(\mathrm{n}: 2) \\
11(\mathrm{n}: 2) \\
14(\mathrm{n}: 7) \\
19(\mathrm{n}: 1) \\
30(\mathrm{n}: 1)\end{array}$ & $\begin{array}{c}7(\mathrm{n}: 1) \\
9(\mathrm{n}: 1) \\
10(\mathrm{n}: 1)\end{array}$ & $\begin{array}{l}1 / 2 \\
1 / 3\end{array}$ \\
\hline Tibia + humerus Kırı̆g & 1 & $22(\mathrm{n}: 1)$ & $14(n: 1)$ & & \\
\hline Yumuşak doku travması & 1 & $22(\mathrm{n}: 1)$ & $14(n: 1)$ & & \\
\hline Alt ekstremitede kısalık & 1 & $20(\mathrm{n}: 1)$ & $5(\mathrm{n}: 1)$ & & \\
\hline \multicolumn{6}{|c|}{ Liste 14. Deri Arızaları ve Yanıklar (n:3) } \\
\hline Kafada atrofik skar & 1 & $1(\mathrm{n}: 1)$ & $11(\mathrm{n}: 1)$ & $5(\mathrm{n}: 1)$ & $1 / 2$ \\
\hline Sağ diz greft onarımı & 1 & $1(\mathrm{n}: 1)$ & $11(\mathrm{n}: 1)$ & $3(\mathrm{n}: 1)$ & $1 / 4$ \\
\hline Yüzün tamamında skar dokusu & 1 & $1(\mathrm{n}: 1)$ & $11(\mathrm{n}: 1)$ & & \\
\hline
\end{tabular}

\section{Tartışma}

Anabilim Dalımıza meslekte kazanma gücünden kayıp oranının tespiti için başvuran olguların değerlendirilmesinde 11.10.2008 tarih ve 27021 sayılı Resmî Gazetede yayımlanan Çalışma Gücü ve Meslekte Kazanma Gücü Kayıp Oranı Tespit İşlemeleri Yönetmeliği ve eklerinden yararlanılmıştır (8). Meslekte kazanma gücünden kayıp oranları; kişinin yaşına, mesleğine ve tespit edilen sekellerin klinik durumuna bağlı olarak değişmektedir.

Muğla Sitkı Koçman Üniversitesi Tıp Fakültesi Adli Tıp Anabilim Dalında Haziran 2015 -Aralık 2016 arasında yaklaşık 1.5 yıllık periyotta sürekli /kalıcı iş göremezlik açısından raporu düzenlenen 259 olgunun \% 70.3'ü erkek, \%29.7'si kadındır. Konu ile ilgili yapılan diğer çalışmalarda da erkek cinsiyette oranın yüksekliği göze çarpmaktadır (1,2,14-16). Van'da yapılan bir çalışmada olguların 2/3'ünden fazlasının erkek olduğu (1), İstanbul'da yapılan bir başka çalışmada 16 olgunun 14'ünün erkek olduğu bildirilmiştir (2). Bu durum erkeklerin motorlu araç kullanımında ve iş hayatında daha çok yer almaları ve daha riskli davranış göstermeleri ile açıklanabilir. Engelli kontenjanı nedeniyle başvuru yapan 5 olgu dışında kalan 254 (\%98) olgu bir trafik kazası sonrası sekel kald1ğı iddiası ile başvurmuştur. Van'da yapılan çalışmada maluliyet için başvuran olguların \%91.6'sını trafik kazaları oluşturduğu (1), Hilal ve ark'nın (17) yaptığı çalışmada olguların \%98.3'ünün trafik kazası nedenli yaralandığ bildirilmiştir.

Olgular yaş gruplarına göre incelendiğinde; en fazla olgunun $(\% 45,2)$ 20-39 yaş grubunda olduğu saptanmıştır (Tablo 1). Benzer çalışmalarda da 20-39 yaş arası olguların sayıca fazlalığı vurgulanmıştır $(1,14-18)$. Bu yaş grubunun aktif çalışma hayatı içinde daha fazla yer aldığı, motorlu araç kullanımının sayıca fazla olduğu, bu yaş 
grubunda tecrübe eksikliğinin ve riskli davranış göstermenin daha fazla olduğu düşünülmüştür.

Kaza ile son muayene tarihi arasında geçen sürelerin değerlendirmesinde; olguların büyük çoğunluğunun (\%29.5) olaydan sonraki 13-18 aylık dönem içinde başvurduğu görülmüștür (Tablo 2). Kazanma gücü kaybı/iș göremezlik kaybı oranı belirlenmesi için iyileşme sürecinin tamamlanması beklenmektedir $(1,4,15)$. Adli Tip Kurumu, tedavi süreci tamamlanma şartı olarak 18 ayı içtihat olarak uygulamalarına sokmuştur (15). Ancak bazı durumlarda çok daha erken sürede iş göremezlik oranları verilebilmektedir. Böyle durumlarda ortopedi, fizik tedavi ve nöroloji uzmanı gibi uzman hekimlere tedavi sürecinin tamamlanıp tamamlanmadığ 1 , süreç içinde hastanın daha fazla iyileşmesinin beklenip beklenmediği sorularak karar verilmelidir. Acar ve ark.'nın (19) yaptı̆̆ çalışmada kırık sekeli sonrası fizik tedavi uygulanan hastaların önceki ve sonraki maluliyet değerlerinin karşılaştırılması yapılmış ve fizik tedavi sonrası 21 olgunun -fizik tedaviye devam edemeyen 2 olgu dışında- maluliyet oranlarının azaldığı saptanmıştır. Bazı olgularda klinik durumun özelliği gereği (ampütasyonlar, organın tamamının çıkarılması gibi) 18 aylık iyileşme sürecinin beklenmesi gerekmemektedir.

Olguların büyük çoğunluğu (\%86.5) özel başvuru ile iş göremezlik oranı talep etmiştir. Geri kalan az bir olgu (\% 13.5) ise Hukuk Mahkemeleri tarafından gönderilmiştir. Mahkemelerin genellikle uyuşmazlık durumlarında olgu yönlendirdiği görülmüş olup, özel başvuru sayısındaki fazlalık ise özel hasar danışmanlık şirketlerinin çoğalmasına bağlanmıştır.

Çalışmamızda iş göremezlik raporu düzenlenen olgularımızın \%24.3'ünde (n:63) birden fazla arıza mevcut olup, bunların 53'ünde ilgili Yönetmeliğin 24. maddesi çerçevesinde Balthazar formülü uygulanmış, 10'unda ise (e) fikrasında belirtildiği üzere listelerde ayrı ayrı gösterilen arızalar, listelerdeki hastalık veya arızanın tabii sonucu olarak değerlendirildiğinden Balthazar formülü uygulanmamıştır. Çalışmada Balthazar formülü uygulanma oranı \%20.5 olarak bulunmuştur. Konya'da yapılan tez çalışmasında olguların \%19.4'ünde birden fazla arızası olduğu ve Balthazar yapıldığı belirlenmiştir (4).

Çalıșmamızda kaza sonrası ilk 6 ayda içinde değerlendirmesi yapılan olguların arızalarına bakıldığında (Tablo 3); olguların çoğunluğunu splenektomi ve tam görme kaybı gibi iyileşme süresi beklenmesine gerek olmayan durumlar ile ilgili Yönetmelik ekindeki cetvellerde sekel bırakmadan iyileşen kemik kırıkları olduğu görülmüştür. Kaza sonras 6 ila 12 aylık süre içinde değerlendirmesi yapılan olguların arızalarına bakıldığında ise (Tablo 4); benzer arızalar yanı sıra ilgili alanlardan uzmanların gö- rüşleri doğrultusunda daha fazla iyileşme beklenmeyen arızalar olduğu tespit edilmiştir.

Raporlarda kalıcı/sürekli iş göremezlik oranları yanı sıra geçici iş göremezlik süresi de verilmiştir. Geçici iş göremezlik süresi 249 olgu için verilmiș ve bu olguların $\% 45.8$ 'inde bu sürenin 90 gün olduğu tespit edilmiştir. (Tablo 5). Geçici iş göremezlik süreleri; arızanın çeşidi, fizyolojik kemik iyileşme süresi, komplikasyon gelişip gelişmediği, kişilerin kaç kez operasyon geçirdikleri, yaş gibi etkenler bir arada değerlendirilerek belirlenmiştir. Çalışma kapsamındaki olgularımızın \%87.4'ünün (n:222) kaza nedeniyle ameliyat olduğu, ameliyat olan olguların \%5'inin 3 veya daha fazla kez ameliyat olmak zorunda kaldı $\breve{g}_{1}, \% 8$ ' inde kırık kaynamasında sorunlar ya da enfeksiyonlar gibi çeşitli komplikasyonlar olduğu saptanmış ve bu durumlar geçici iyileşme süreleri belirlenirken dikkate alınmıştır. Arızalar aynı olsa dahi araya giren komplikasyonlar nedeniyle bu sürelerin kişiden kişiye değişebileceği göz önüne alınmalıdır. Bu konuda ortak bir uygulama birliği için çalışmalar yapılmalıdır. Konya'da yapılan tez çalışmasında iyileşme süreleri belirlenirken yaş ve fizyolojik kemik iyileşme sürelerinin dikkate alındığı bildirilmiş, iyileşme sürelerinin 15 gün36 ay arasında değiştiği, olguların $\% 45,8$ 'inde iyileşme süresinin 6 veya 9 ay olarak hesaplandığı bildirilmiştir (4). Aynı çalışma olguların \%67.8'inin olay nedeniyle ameliyat olduğunu da belirtmiştir.

Tablo 6-7 ve 8 olguların arıza listelerine göre tan1larını, arıza ağırlık ölçülerini ve takdir oranlarının olgu sayısına göre dağılımını vermektedir. Bu çalışmada toplamda 73 olgudaki arıalara (\%23.1) takdir uygulanmıştır. Gürbüz'ün çalışmasında (4) olguların \%23.5'ine bir takdir oranı verildiği bildirilmektedir. Çalışma hangi oranlarda takdir uygulandığını vermiş, en fazla $2 / 3$ oranında oranın azaltıldığını bildirmiştir. Hilal ve ark'nın (17) çalışmasında olguların \%21.7'sinde kısıtlılı̆̆ 1 tam karşılayan bir madde olmaması nedeniyle takdir uygulandığı vurgulanmıştır. Kaya ve ark.nın (20) çalışmasında ise takdir uygulama oranı olguların \%35.8'i için bildirilmiştir.

Çalışmamızda takdir uygulanan tanılara bakıldığında (Tablo 6,7,8); en fazla takdir uygulanan bölgeler; omuz, dirsek, kalça, vertebra ile yüz bölgesinde sabit eser niteliğinde skar dokuları ve travma kaynaklı ruhsal bozukluklar olmuştur.

Hilal ve ark.nın (17) çalışmasında benzer şekilde takdir uygulanan vücut bölgeleri omuz (\%38.1), kalça (\%15.4) ve el bileği (\%8.4) olarak bildirişmiştir.

Çalışma Gücü ve Meslekte Kazanma Gücü Kayıp Oranı Tespit İşlemleri Yönetmeliği'nin eklerinde belirtilen arıza listesinde bazı arızaların tam karşılığı bulun- 
mamakta ya da kişilerin klinik durumları ve sekellerinin/ kısıtllılıklarının ağılık düzeyleri farklılıklar gösterebilmektedir. Bu durumlarla karşılan hekimler oran belirlerken takdir hakkını kullanmaktadır. Ancak bu durum aynı sekelde ve aynı klinik durumda bile hekimden hekime farklı takdir oranları şeklinde karşımıza çıkabilmektedir $(4,17,20,21)$. İlgili Yönetmelikte farklı klinik durumları gözetecek şekilde oranlar belirlenmemiştir, farklı klinik bulgularda oranların hangi sekel düzeyinde olacağı net değildir. Bu konuda uygulama birliğine, güncel tedavi yaklaşımları düşünülerek arıza ağırlık cetvelinin yenilenmesine ve adli tıp ve branş hekimlerinin birlikte yürüteceği çok kapsamlı bir çalışmaya ihtiyaç olduğu kanısındayiz.

Çalışmamız kapsamında kalıcı iş göremezlik oranı vermede kullandığımız 'Çalışma Gücü ve Meslekte Kazanma Gücü Kaybı Oranı Tespit İşlemleri Yönetmeliği'ndeki meslekte kazanma gücü kayıp oranı tespit cetvelleri Ek-3’te arıza ağırlık ölçüsünü gösteren arızalar ile ilgili takdir oranı uyguladığımız sekeller tek tek irdelenecek olursa;

- Çalışmamızda 2 olgu 'anksiyete' ve 2 olgu da 'depresyon' tanıları almıştır. İlgili Yönetmelik eklerinde mevcut arıza listelerinde Liste 1- Baş Arızalarında her iki hastalık da yer almamaktadır. Bu liste kapsamında bu hastalıklar tarafimızdan Arıza Sıra No: 16 'Nevrotik bozukluk, kişilik bozuklukları ve başka psikotik olmayan ruhsal bozukluklar' kapsamında, 'Nevrotik bozukluklar' alt sınıfinda 'Tedavi ile çalışma olanağı veren' arızalara dahil edilmiştir. Olguların klinik durumları ve işlevsellik düzeylerine göre oranlara $1 / 3$ ve $1 / 4$ oranlarında takdir uygulanmıştır. Benzer şekilde özellikle travmalar sonrası en sık karşılaşılan ruhsal tanılardan olan Travma Sonrası Stres Bozukluğu tanısının da cetvelde yer almamasını ve işlevsellik düzeyine göre oranların net olmamasını sık karşılaşılan sorunlu alanlardan biri olarak düşünmekteyiz. Gürbüz (4) de alışmasında Travma Sonrası Stres Bozukluğu tanısını sorunlu tanılardan biri olarak bildirmiştir.

- Yine çalışmamızda 1 olguda mevcut yüz kemik k1rıkları nedenli gelişmiş 'maloklüzyon' sekeli yer almaktadır. Bu sekel tarafımızdan Liste 4- Yüz Arızaları- Arıza Sıra No: 1 'Çiğneme ve konuşmayı ileri derecede güçleştiren alt ve üst çene kırık sekeli’ kapsamında değerlendirilmiş ve kişinin maloklüzyon derecesi, çiğneme düzeyi ve konuşma düzeyine göre $2 / 3$ oranında indirim yapılarak takdir uygulanmıştır. Benzer şekilde yüz arızalarında diş kayıpları da bütün dişlerin kaybı şeklinde oranlanmıştır. Oysa ki birden fazla alveol kaybı olduğunda cetvelde belirlenmiş oran, klinik durum için yüksek kalmaktadır. Bu arızalar için de klinik duruma ve işlevsellik düzeylerine göre oranların net olmasına ihtiyaç duyulmaktadır. Yüz arızaları arasında; anosmi (koku alma duyusu kaybı) olan bir olgumuz bulunmaktadır. Listede Arıza sıra no: 6'da 'Koklama ve tatma duygularının azalması' arızasının arıza ağırlık ölçüsü 10 olarak belirlenmiştir. Koklama ve tatma duyularının azalması olan hiposmi sekeli listelerde yer alırken, koku alma duyusunun tam kaybı olan anosmi sekeli listelerde yer almamaktadır. Benzer şekilde duyu bozuklukları arasında koku ile ilgili kokuyu sürekli kötü bir şekilde algılama gibi farklı klinik durumlar da söz konusu olabilmektedir. Böylesi durumlar için daha net oranlara ihtiyaç vardır. İlgili uzmanlık alanınca konsültasyon ve testlerle 'anosmi' tespit edilen olgumuz, en yakın karşıllığı olarak Arıza sıra no:6 kapsamında değerlendirilmiş ve herhangi bir takdir oranı uygulanmamıştır.

- Liste 7- Omuz ve Kol arızaları bölümünde 22 olguya takdir oranı uygulandığı görülmüştür. Omuz çıkığ1, skapula kırığı, radius ulna kırığı, olakranon kırığı, humerus kırı $\breve{g} 1$, klavikula kırığı gibi tanılarımız sonucu meydana gelen omuz ekleminde hareket kisitlılık oranları ekli listelerde yer almamaktadır. Tarafımızdan omuz ekleminde hareket kısıtlılı̆ğ ya da ankiloza neden olan durumlar Ariza sira no: 2 (omuz eklem ankilozu) ya da Arıza sıra no 3: Omuz ve kolda çalışmayı zorlaştıran tendosinovit, bursit kapsamında değerlendirilmiş ve eklemde yarattığı hareket kısıtlılığının derecesine göre azaltılarak takdir uygulanmıştır. Ekli listeler de omuz ampütasyonlarının yer almaması da bir başka sorun olarak karşımıza çıkabilmektedir. Yine Omuz-Kol arızaları içinde sinir yaralanmalarına bağlı paraliziler yer almakta ancak sinir yaralanmalarına bağl -motor - duysal-birleşik hasarlar için ve hasarın düzeyine göre ayrı ayrı bir oran yer almamaktadır. Bu nedenle N. Radialis, N. Medianus ve N. Ulnaris yaralanması olan toplam 4 olgumuzda cetvelde bildirilen arıza ağırlık ölçülerinde klinikleri düzeylerine göre oranlar azaltılarak takdir uygulanmıştır.

- Liste 8: El Bileği ve El Arızalarında; radius kırığı, ulna kırı̆̆ı, ön kol çift kırığı, radius kırığı-ulna çıkığı nedenli gelişen farklı klinik durumlar için 13 olguya takdir uygulanmıştır. Liste 9- el parmak arızaları kapsamında ise takdir uyguladığımız bir olgu bulunmamaktadır.

- Liste 10: Omurga arızaları kapsamında; vertebrada kompresyon kırı̆gı olan 6 olguya ve vertebra posterior eleman kırığı (transvers proçes kırığı) olan 1 olguya takdiren indirim uygulanmıştır. Cetvelde kompresyon kırıklarının düzeylerinin netleşmesi yanı sıra bel- 
boyun hareket açıklıklarının da değerlendirilebileceği şekilde eklem hareket açıklıklarının net bir şekilde karşıllı̆ı olmasına, olguların klinik durumlarına göre net oranların verilebileceği șekilde düzenleme yapılmasına ihtiyaç olduğu kanısındayız.

- En fazla takdir uygulanan bir başka liste ise Liste 12Pelvis ve Alt Ekstremite Arızaları olmuştur. Așil tendon yırtığı, femur kırığı, pelvis kırığı, tibia kırığı, tibia-fibula kırı̆ğ nedenli gelişen farklı klinik durumlar için 25 olguya takdir uygulanmıştır. Liste 12 'de 'Tibianın, fibulanın veya krurisin iyileşmiş, komplikasyonsuz kırıkları' bir sekele neden olmasa da cetvelde yer almıştır. Birçok olgu sekel olmasa dahi sadece bu kemik kırıkları nedenli bir maluliyet oranı alabilmektedir. Buna karşı1ık aynı listede vücudun en büyük kemiği olan 'femur kırı̆ı' ise tibia-fibula kırıkları gibi tek başına oranlanmamıştır. Çalışmamızda 19 olguya tibia ya da tibia- fibula komplikasyonsuz kırıkları nedenli oran verilirken, 9 olguya ise femur komplikasyonsuz kırı̆ğ cetvelde yer almamasına rağmen kıyasen aynı arıza ağırlık ölçüsünden (Liste 12-Arıza sıra no:32) oran verilmiş ve olguların kliniği ölçüsünde takdir uygulanmıştır.

- Benzer şekilde listelerde tibia ve fibulanın angulasyonu arızasına yer verilirken, femur angulasyonu arızasına yer verilmediği görülmektedir. Femur kırığı nedenli meydana gelebilecek olan sekeller (kalça eklem hareket kısitlılıkları, ankilozu, angülasyon, yürüme bozuklukları, atrofi ve kısalıklar gibi) listede net olarak yer almadığı için femur kırıkları aynı zamanda Arıza sıra no 34 kapsamında (kalça (trokanter) ve bacakta çalışmayı etkileyen tenosinovitler, bursitler, periostitler) kapsamında değerlendirilmiştir. Bu kapsamda değerlendirilen 10 olgumuza klinikleri oranında takdir uygulanmıştır.

- Takdir uyguladığımız bir başka liste de Liste 14: Deri Arızaları ve Yanıklar listesi olmuştur. Kafada atrofik skar olan bir olguya ve sağ dizde greft onarımı yapılan bir olguya Arıza sıra no; 1, (vücut yüzeyinin \% 10'unu kaplayan keleoid hipertrofik skar) kapsamında ve skarın kapladığı alanın da yanık alanının genișliğinde kullanılan dokuzlar kuralı baz alınarak, kıyaslama yapılmış ve takdiren indirim uygulanmıştır. Yüzün tamamını kaplayan skarı olan bir olgumuzda ise takdir uygulanmamıştır. Yüz yaralanmaları özellikle yüzde sabit iz yaratacak nitelikte yaralanmalarsa, kişinin iş sürekliliğini ve iş bulmasını etkilemesi açısından değerlendirmeye aldığımız olgular olmuştur. Diğer yandan, ameliyat nedenliyle kişilerde oluşabilecek skarlar bir sekel olarak değerlendirilmemekte ve oranlara dahil edilmemektedir.
Ülkemizde kalıcı iş göremezlik oranlarının tespitinde kullanılan 'Çalışma Gücü ve Meslekte Kazanma Gücü Kayıp Oranı Tespit İșlemleri Yönetmeliği’ aslında iş kazaları ve meslek hastalıkları için hazırlanmış olmasına rağmen bu oranların hesaplamasında kullanılacak bașka bir yönetmelik bulunmadığı için trafik kazaları ve diğer kazalar sonucu gelişen arızaların tespiti için de kullanılmaktadır.

Bir başka özür oranı tespiti yapılan cetvel olan; 'Özürlülük Ölçütü, Sınıflandırılması ve Özürlülere Verilecek Sağlık Kurulu Raporları Hakkında Yönetmelik' ise kişilerin pek çok özlük hakları ile ilişkili özürlülüklerinin belirlenmesi için düzenlenmiştir. Yaralanmalardan çok kişiler bir bütün olarak değerlendirilip, yaş ve mesleği dikkate alınmadan özür oranları belirlenmektedir. Kullanılan iki cetvel de travmatik durumların kişilerde bırakmış olduğu sekellere özgü değildir.

\section{Sonuç}

Çalışmamızda takdiren ya da kıyasen indirim yapılan sekellerin ilgili Yönetmeliğin sorunlu alanları olduğunu düşünmekteyiz. Tespit ettiğimiz sorunlu alanlardan farklı sorunlar olduğunu bildiren çalışmalar da bulunmaktadır $(4,16,17,20,21)$. Uygulamada aynı sekelde ve aynı klinik durumda bile hekimden hekime farklı takdir oranları olabilmektedir. Maluliyet oranlarının hesaplanmasında bir standardizasyona ihtiyaç vardır. Bu nedenle Yönetmelikte belirtilen arızaların farklı klinik durumlar için net bir şekilde hesaplanır olabilmesi, daha anlaşılır bir dilde hazırlanması, muayene ve yorum farkl111klarına izin vermemesi için güncellenmesi gerektiği kanısındayız. Adli tıp ve diğer uzmanlık alanlarından hekimlerin birlikte yürüteceği, ortak bir yaklaşımın geliştirileceği çok kapsamlı bir çalı̧̧maya ihtiyaç olduğu düşüncesindeyiz.

\section{Kaynaklar}

1. Hekimoğlu Y, Gümüş O, Kartal E, Etli Y, Demir U, Aşirdizer M. Maluliyet Oranlarının Yaş ve Cinsiyet İle İlişkisinin Değerlendirilmesi. Van Tip Derg 2017; 24(3): 173-181. DOI: $10.5505 /$ vtd.2017.53244.

2. Ünal V, Ünal E., Yener Z, Çetinkaya Z, Çağdır S. Fark Hesabına Dayalı Maluliyet Oranı Tespiti. Turkish J Fam Med Primary Care. 2015;12(2):37-46.

3. World Health Organization. Disability Prevention and Rehabilitation. Geneva: World Health Organization; Technical Report Series 668, Geneva 1981.

4. Gürbüz V. 2013-2016 y1lları arasında Necmettin Erbakan Üniversitesi Meram Tıp Fakültesi Hastanesi Adli Tıp Anabilim Dalı tarafından yazılan maluliyet raporlarının değerlendirilmesi, ülkemizdeki ve dünya çapındaki kıyaslamaları. Uzmanlık Tezi. Danışman Şerafettin Demirci, Konya, 2017.

5. ILO, Özürlülerin Mesleki Rehabilitasyonu, Tavsiye no:99, 1995. 
6. TUİK 2015 yıl1 raporu: http://www.tuik.gov.tr/PreHaberBultenleri.do?id=21611, (Erişim tarihi: 20.12.2017.

7. TUİK 2016 y1l raporu: www.tuik.gov.tr/PdfGetir. do?id=24606. (Erişim tarihi: 20.12.2017)

8. Çalışma Gücü ve Meslekte Kazanma Gücü Kaybı Oranı Tespit İşlemleri Yönetmeliği. Resmi Gazete Tarihi: 11.10.2008 Resmi Gazete Say1s1: 27021. http://www.mevzuat.gov.tr/ Metin.Aspx?MevzuatKod=7.5.12511\&MevzuatIliski=0\&s ourceXmlSearch. (Erişim tarihi: 20.12.2017).

9. Sosyal Sigortalar Ve Genel Sağlik Sigortasi Kanunu Kanun Numarası: 5510 Resmî Gazete: Tarih: 16/6/2006 Sayı: 26200 . http://www.mevzuat.gov.tr/MevzuatMetin/1.5.5510.pdf. (Erişim tarihi: 20.12.2017).

10. Ongun AC. Trafik ve İş kazasında Yargıtay uygulamaları ile aktüeryal tazminat hesaplamaları. http://www.tbbegitim. com/dokuman/ekutuphane_trafikveiskazasinda.pdf. (Erişim tarihi 22.12.2017).

11. Özürlülük Ölçütü, Sınıflandırılması ve Özürlülere Verilecek Sağlık Kurulu Raporları Hakkında Yönetmelik. Resmi Gazete, Say1: Say1: 28603, tarih: 30.03.2013. http://www.resmigazete.gov.tr/eskiler/2013/03/20130330-4.htm. Erişim tarihi 22.12.2017).

12. 65 Yaşini Doldurmuş Muhtaç, Güçsüz Ve Kimsesiz Türk Vatandaşlarina Aylik Bağlanmasi Hakkinda Kanun İle Bazi Kanun Ve Kanun Hükmünde Kararnamelerde Değişiklik Yapilmasina Dair Kanun. Resmi Gazete: Kabul no: 6704, Kabul tarihi: 14.04.2016. http://www.resmigazete.gov.tr/eskiler/2016/04/20160426-11.htm. (Erişim tarihi 22.12.2017).

13. Cantürk G. Maluliyet raporlarında yaşanan sorunlar. In: Hanc1 İH, Ünver Y, editors. III. Sağlık Hukuku Kongresi Kongre Kitabı. Ankara: Seçkin Yayıncılık, 2006: p. 29-40.
14. Birgen N, Okudan M, Inanıcı MA, Okyay M. İş Kazasına Bağlı Olgularda Maluliyet Oranı Hesaplanması: Adli Tıp Açısından Değerlendirilmesi. Adli Tıp Bülteni. 1999;4(3):101-8. DOI: 10.17986/blm.199943374

15. Ünal V, Yurtseven A, Erdoğan M, Anolay N, Ünal E., Baklacıŏlu F. Travma Sonrası Meydana Gelen Alt Ekstremite Amputasyonlarında Etiyoloji ve Maluliyet Değerlendirilmesi Adli Tıp Bülteni. 2016;21(1):31-8. DOI: 10.17986/ blm.2016116598

16. Buluş E, Menkü ŞF, Delil Ş, Özkara Ç, Yeni SN. Maluliyet Belirlenmesi Amacıyla Hastanede Yatırılan Epilepsi Hastalarına Yaklaşım. Epilepsi 2015;21(1):29-33. DOI: 10.5505/ epilepsi.2015.54227.

17. Hilal A, Akgündüz E, Kaya K, Yılmaz K, Çekin N. Çukurova Üniversitesi Tıp Fakültesi Adli Tıp Anabilim Dalına Gelen Maluliyet Raporlarının Retrospektif Olarak Değerlendirilmesi. Adli Tıp Bülteni. 2017;22(3): 189-193. .DOI: 10.17986/blm.2017332032

18. Sözen Ş, İnce H, Dikici F, Diraçoğlu D, İnce N. Maluliyet (Meslekte Çalışma Gücü Kayıplarının) Hesaplanması. Klin Gelişim. 2009;22(19):122-5.

19. Acar K, Ardıç F, Toraman F. Kırık Sekeli Nedeniyle Fizik Tedavi Gören 21 Olgunun Adli Tıp Açısından İrdelenmesi. Adli Tıp Bülteni. 1996;1(2):64-7.

20. Kaya A, Meral O, Erdoğan N, Aktaş EÖ. Maluliyet Raporlarının Düzenlenmesi: Anabilim Dalımıza Başvuran Olgu Özellikleri. Adli Tıp Bülteni, 2015;20(3):144-151. DOI: 10.17986/blm.2015314259.

21. Hilal A. Maluliyet Hesaplamalarında Karşılaşılan Sorunlar. Adli Tıp Bülteni, 2016; 21(2). DOI: 10.17986/ blm.2016220387 